\title{
Basic principles and ecological consequences of altered flow regimes for aquatic biodiversity ${ }^{1}$
}

\author{
Short Title: Flow regimes and aquatic biodiversity \\ Stuart E. Bunn ${ }^{2}$ and Angela H. Arthington
}

Cooperative Research Centre for Freshwater Ecology,

Centre for Catchment and In-Stream Research,

Faculty of Environmental Sciences,

Griffith University, Nathan, Queensland, Australia 4111

1. This is a contribution of the Scientific Committee on Water Research (SCOWAR) of the International Council for Science (ICSU).

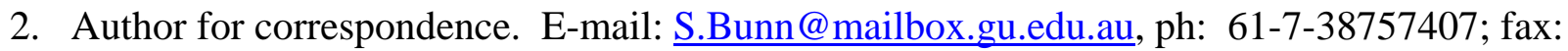
61-7-38757615

Environmental Management 30, 492-507. 


\begin{abstract}
The flow regime is regarded by many aquatic ecologists to be the key driver of river and floodplain wetland ecosystems. We have focussed this literature review around four key principles to highlight the important mechanisms that link hydrology and aquatic biodiversity and to illustrate the consequent impacts of altered flow regimes: Firstly, flow is a major determinant of physical habitat in streams, which in turn is a major determinant of biotic composition; Secondly, aquatic species have evolved life history strategies primarily in direct response to their natural flow regimes; Thirdly, maintenance of natural patterns of longitudinal and lateral connectivity is essential to the viability of populations of many riverine species; Finally, the invasion and success of exotic and introduced species in rivers is facilitated by the alteration of flow regimes. The impacts of flow change are manifest across broad taxonomic groups including riverine plants, invertebrates and fish. Despite growing recognition of these relationships, ecologists still struggle to predict and quantify biotic responses to altered flow regimes. One obvious difficulty is the ability to distinguish the direct effects of modified flow regimes from impacts associated with land-use change that often accompanies water resource development. Currently, evidence about how rivers function in relation to flow regime and the flows that aquatic organisms need exists largely as a series of untested hypotheses. To overcome these problems, aquatic science needs to move quickly into a manipulative or experimental phase, preferably with the aims of restoration, and measuring ecosystem response.
\end{abstract}

KEYWORDS: ecological principles, hydrology, aquatic biodiversity, flow regime, life history, longitudinal connectivity, lateral connectivity, introduced species

\title{
Introduction
}

The alteration of flow regimes is often claimed to be the most serious and continuing threat to ecological sustainability of rivers and their associated floodplain wetlands (Naiman and others 1995; Sparks 1995; Lundqvist 1998; Ward and others 1999). While the obvious and often irreversible impacts of large impoundments are now well recognised, there is also growing awareness of the pivotal role of the flow regime as a key 'driver' of the ecology of rivers and their associated floodplain wetlands (Junk and others 1989; Poff and others 1997; Richter and others 1997; Puckridge and others 1998; Hart and Finelli 1999). 
The primary goal of this review is to illustrate how altering flow regimes affects aquatic biodiversity in streams and rivers. To do so, we pose four guiding principles about the influence of flow regimes on aquatic biodiversity (see also Figure 1), and examine the consequences of changing flow regimes in light of each of these. The principles are:

Principle 1: Flow is a major determinant of physical habitat in streams, which in turn is a major determinant of biotic composition

We outline the influence of flow on stream habitats at the catchment scale (e.g., channel dimensions), reach scale (e.g., riffle-pool distribution) and patch scale (e.g., hydraulic conditions on individual stones), and discuss how habitat in turn influences the distribution and abundance of aquatic organisms. We then examine how modified flow regimes alter habitat at varying spatial scales and the influence of this on species distributions and abundance, as well as the composition and diversity of aquatic communities.

Principle 2: Aquatic species have evolved life history strategies primarily in direct response to their natural flow regimes

We discuss the degree to which flow pattern has a major influence on shaping life history patterns of aquatic species. We then consider how alteration of flow regimes can lead to recruitment failure and loss of biodiversity of native species.

Principle 3: Maintenance of natural patterns of longitudinal and lateral connectivity is essential to the viability of populations of many riverine species.

We discuss how the viability of populations of many species of fully aquatic organisms depends on their ability to freely move through the stream hierarchy, or between the river and floodplain wetlands. Loss of longitudinal and lateral connectivity through construction of barriers can lead to isolation of populations, failed recruitment and local extinction.

Principle 4: The invasion and success of exotic and introduced species in rivers is facilitated by the alteration of flow regimes

Here, we briefly discuss the overall impact of modifying flow regimes on the establishment, spread, and persistence of exotic and introduced species. We also consider interbasin transfers of water as a major mechanism for the spread of exotic and introduced species, as well as disease. 


\section{Principle 1: Flow is a major determinant of physical habitat in streams, which in turn is a major determinant of biotic composition}

Flow influences on habitat

The movement of water across the landscape influences the ecology of rivers across a broad range of spatial and temporal scales (Vannote and others 1980; Junk and others 1989; Poff and Ward 1990; Poff and others 1997; Sparks 1995). The shape and size of river channels, the distribution of riffle and pool habitats, and the stability of the substrate are all largely determined by the interaction between the flow regime and local geology and landform (Frissel and others 1986; Cobb and others 1992; Newbury and Gaboury 1993). In turn this complex interaction between flows and physical habitat is a major determinant of the distribution, abundance and diversity of stream and river organisms (Schlosser 1982; Poff and Allan 1995; Ward and others 1999; Nilsson and Svedmark 2002). This is evident at even the smallest spatial scales, where subtle variations in flow and near-bed velocities can dictate the distribution and abundance of particular species of plants and animals (e.g., Wetmore and others 1990). Close associations with physical habitat can be found in many stream organisms ranging from algae and aquatic plants to invertebrates and fish.

\section{Influence of flow and habitat on aquatic plants}

The most commonly cited abiotic determinants of aquatic macrophyte assemblage structure are all flow-related factors (e.g., flow extremes, flow regime, hydraulics, substrate composition and stability). Spatial and temporal variation in plant assemblage structure is influenced by flooding and scouring, desiccation, substrate stability and localized variations in water velocity, turbulence and shear stress (Chambers and others 1991; Biggs 1996, French and Chambers 1996). Aquatic macrophytes typically have patchy distributions as a result of spatial variations in disturbance frequency and intensity, colonization success and growth rates (Sand-Jensen and Madsen 1992; Rea and Ganf 1994).

Flow modifications to Scandinavian rivers (Rørslett and others 1989) and many rivers in the United States, Britain, France, southern Africa, India, Canada and Australia are responsible for increases in macrophyte abundance (see Table 1). For example, reduced summer floods and increased winter flows (i.e., a relatively stable flow throughout the year) cause excessive growths of submerged aquatic macrophytes in Norwegian rivers regulated by hydropower stations. Up to 
$55 \%$ of tailwater surface area and slow-flowing reaches further downstream in the River Otra were covered with prolific growths of the submerged phenotype of Juncus bulbosus L. (Rørslett 1988). In its pristine state, the flow regime of the Otra featured low winter flows and spring/summer floods, conditions that exposed plants to extreme stress caused by frost and ice scouring followed by the deleterious scouring effects of spring floods. The regulated regime ameliorates all of these conditions, allowing plants to accumulate massive biomass in regulated reaches.

Numerous species of aquatic plants from permanent backwaters and wetlands on the floodplain of the highly regulated lower Murray River in southeastern Australia have colonized the main channel, where the year-round baseflow in weir pools now provides ideal conditions (Walker and others 1994). Blanch and others (2000) suggest that reinstating greater amplitude of weir pool water levels, more frequent shallow flooding and longer periods of inundation would be beneficial for many plant species, promoting diversity by restoring a wider range of water regimes (Table 1).

\section{Influence of flow and habitat on aquatic invertebrates}

Physical disturbance from floods (and droughts) is thought to be a major determinant of the spatial and temporal dynamics of benthic communities in streams (e.g., Resh and others 1988). Rivers with unstable substrates tend to be characterized by low species diversity and the biota present often have life history or behavioral characteristics of frequently disturbed environments (Sagar 1986; Cobb and Flannagan 1990; Cobb and others 1992).

Macroinvertebrates are vulnerable to rapid diurnal changes in flow and regulated river reaches below hydroelectric dams, with erratic flow patterns, are typically characterized by species-poor macroinvertebrate communities (Munn and Brusven 1991; Table 1). Sudden increases in flow can cause catastrophic downstream drift to the extent that as much as $14 \%$ of the standing crop of benthic biota can be eliminated each month in some hydropower operations due simply to drift resulting from increased shear stress (Layzer and others 1989). The impact of high flow water releases below hydropower dams can be very selective. Small insect nymphs and invertebrates, which cannot tolerate high velocities, are often under-represented in downstream reaches (De Jalon and others 1994). 
In some cases, flow regulation may favor the proliferation of specific taxa (e.g., orthoclad chironomids; Munn and Brusven 1991; Table 1). Since the construction of impoundments on the Lower Vaal River, South Africa, regulation of the once sporadic winter flow regime has allowed large populations of blackfly (Simuliidae) larvae to survive the winter and led to periodic plague outbreaks of adults in spring (De Moor 1986). It has been suggested that this pest species, which poses a health risk in the region, can be controlled to some extent by careful water level manipulations (De Moor 1986).

\section{Influence of flow and habitat on fish}

Many fish species display a preference for particular types of habitat such as pools, riffles or backwater areas (Matthews 1985; Angermeier 1987; Pusey and others 1993). The richness of the fauna often increases as habitat complexity increases, with depth, velocity and cover being the most important variables governing this relationship (Gorman and Karr 1978; Schlosser 1982; Felley and Felley 1987; Pusey and others 1995). Fish assemblage structure (i.e., taxonomic composition and relative abundance pattern) is also strongly related to habitat structure (Meffe and Sheldon 1988; Pusey and others 1993; 1998; 2000).

Associations between fish and their habitat are influenced by flow variability at a range of spatial scales. Poff and Allan (1995) demonstrated regional differences in fish assemblage structure and functional organization in streams of differing flow variability in the northern mid-western United States. Hydrologically variable streams (i.e., those with high coefficient of variation of daily flows, moderate frequency of spates) were characterized by species with generalized feeding strategies, and preference for low water velocity, silt and general substrata. In more stable streams, with high predictability of daily flows and stable baseflows, fish assemblages contained more silt-intolerant trophic specialists (Poff and Allan 1995).

Flow variability and habitat structure at smaller spatial scales within the drainage network can also influence fish assemblages. Pusey and others (1993) showed that stream discharge regime varied spatially in the Mary River, south-east Queensland, Australia, with some small tributaries prone to frequent periods of extended zero flows, whereas others have very constant baseflows. Tributaries with extended periods of low flow were dominated by small, physiologically tolerant and generalist species (Pusey and others 1993). 
Given the often-cited relationships between flow, habitat structure and fish, it is not surprising that modifications to flow regimes affect fish diversity and the functional organization of fish communities in regulated rivers (Table 1). Impacts may involve any life history stage and have been observed at all spatial scales. For example, pulsed reservoir discharges associated with ondemand hydroelectric power generation limit the quality and quantity of habitat available (Reiser and others 1989; Valentin and others 1994; 1995). Stream fish can become stranded on gravel bars or trapped in off-channel habitats during rapid flow decreases. Susceptibility to stranding is a function of behavioral response to changing flows, and this varies with species, body size, water temperature, time of year and day, substrate characteristics and the rate of flow reductions (Bradford 1997). For example, newly emerging salmon larvae, and juvenile salmonids hiding in the stream substrates during winter, are extremely susceptible to being stranded in the substrate during flow reductions (Bradford and others 1995; Bradford 1997). However, mature fish may be able to shift into temporarily suitable habitats to compensate for periodic reductions in the quality or availability of habitat (Kraft 1972; Bunt and others 1999).

The humpback chub (Gila cypha) historically ranged throughout the Colorado River system in the arid American southwest, living in swift canyon reaches now inundated or decimated by water development projects (Converse and others 1998). Operations of the Glen Canyon Dam directly affect the Colorado River through changes in flow, temperature, sediment transport and vegetation dynamics. Peak flows are considered important to the chub for habitat maintenance (via sediment transport) and perhaps as spawning cues, but base flows, which occur through the Grand Canyon for 7 to 10 months of the year, are also important. Elevated base flows now occur a greater proportion of the time in the regulated flow regime, and reduce habitat quality to the extent that sub-adult humpback chub are now much more numerous in the modified shoreline habitat provided by the exotic tamarisk (Tamarix chinensis) than in natural habitats (Converse and others 1998). In addition, the dam has altered the thermal regime such that the growth, reproduction and survival of native fishes have almost certainly been affected (e.g., Bulkley and others 1981).

\section{Conversion of lotic to lentic waterbodies}

It is often argued that the loss of riverine habitat associated with impoundments is balanced by the creation of lake habitat. This is somewhat misleading, however, as natural lakes and 
wetlands often function in a very different way than river storages. In lakes and wetlands, much of the carbon and nutrient fluxes occur in the littoral margins (Bunn and Boon 1993; Wetzel 1990). Large impoundments are generally not operated at a constant water level, and productive littoral areas are rarely sustained. In addition, water levels are usually significantly elevated above natural stream levels, flooding part of the terrestrial-aquatic interface and creating a new littoral zone with steeper banks, less complex aquatic habitat and different physico-chemical conditions for aquatic plants and animals (Walker and others 1992).

The effects of weirs on river flow regimes and aquatic habitat can be complex and difficult to separate from the effects of exotic species, which often proliferate in the newly created lake habitat (see Principle 4). In the Lower Murray River in southeastern Australia weirs have transformed the river into a chain of cascading pools, supplanting most of the riverine environment with pool habitats (Walker and others 1992). This has affected the distribution of the Murray Crayfish (Euastacus armatus), now close to extinction, and several species of riverine and wetland snails have declined (Table 1).

Regulation of the lowland river Great Ouse, UK by weirs, embankments, navigation locks and dredging has converted it into a series of relatively deep "reservoir-like” channels, separated by short, shallow lotic stretches. Impacts on fish include the absence of localized salmonids and pelagic spawning fishes (i.e., burbot) historically reported to be abundant, reduction in the range and abundance of rheophilic and limnophilic cyprinids, and the extreme dominance of generalist species (roach and minnows) throughout most of the system (Copp 1990).

The Colorado River is regulated by hundreds of reservoirs varying in area from less than 1 ha in high altitude headwaters to more than $650 \mathrm{~km}^{2}$ in lowland mainstem segments (Stanford and Ward 1986a). Conversion of one quarter of the river to lentic habitat has resulted in the loss of fishes adapted to turbid riverine habitats. In addition, numerous introductions of highly competitive exotic fishes (over 50 species), many thriving in impoundments and regulated river reaches, have contributed to the extirpation of native fishes in the Colorado River fauna (Stanford and Ward 1986b). Most of the native big-river fish face extinction (Stanford and Ward 1986b). In the headwaters of the upper basin, the range of the Colorado River cutthroat trout 
(Salmo clarki pleuriticus) is limited to a few isolated populations, and nearly all of the endemic desert stream fish are in severe decline.

\section{Principle 2: Aquatic species have evolved life history strategies primarily in direct response to their natural flow regimes}

Influence of flow regime on life history patterns

The influence of river flows and wetland water regimes on recruitment and growth of aquatic plants is well established (Table 2). Changes in rates of water level fluctuation, disturbance frequency (floods and spates) and intensity (velocity and shear stress) can affect seedling survival, as well as plant growth rates (Blanch and others 1999, 2000; Froend and McComb 1994; Rea and Ganf 1994; Sand-Jensen and Madsen 1992). Rea and Ganf (1994) suggest that changes in water regime have a profound effect on the establishment and survival of many aquatic plant species owing to their narrow range of tolerances and inability to regenerate under modified conditions. Conversely, the proliferation of species such as Typha in numerous artificial and altered aquatic habitats throughout southern Australia (Rea and Ganf 1994; Blanch and others 1999, 2000) is a function of several life history traits. These include high dispersal capabilities (production of large numbers of small seeds dispersed by wind over long distances), a high capacity to germinate while submerged (Finlayson and others 1983), high seedling density and, once established, rapid growth rates and vegetative reproduction (Froend and McComb 1994).

Although temperature regimes influence the life history patterns of many stream and river animals, the timing of particular flow or inundation events is also important (Sweeney 1984; Resh and others 1988) (Table 2). For example, temperature is a major factor influencing breeding in atyid shrimps (Atyidae) (e.g., de Silva 1988a, b). However, life history patterns are also strongly modified by the prevailing hydrology (see Hancock and Bunn 1997). Many Australian and New Zealand stream invertebrates have flexible life history patterns, which are thought to be a direct response to highly variable and unpredictable discharge regimes (Winterbourn and others 1981; Marchant and others 1984; Lake and others 1985). Evidence of greater synchrony of development is found only in regions with a more predictable flow regime (e.g., Bunn 1988). A spectacular example of the influence of flow on aquatic biota is the 'boom or bust' dynamics of Australian arid 
zone rivers and wetlands, in response to unpredictable and episodic flood events (Walker and others 1995).

Flow plays a profound role in the lives of fish with critical life events linked to flow regime (e.g., phenology of reproduction, spawning behaviour, larval survival, growth patterns and recruitment) (Welcomme 1985; Junk and others 1989; Copp 1989, 1990; Sparks 1995; Humphries and others 1999). Many of these life events are synchronized with temperature and day-length such that changes in flow regime that are not in natural harmony with these seasonal cycles may have a negative impact on aquatic biota.

Many species in streams with highly variable flow regimes have evolved life history strategies that ensure strong recruitment despite the disturbances wrought by spates (Table 2). Humphries and Lake (2000) proposed the "low flow recruitment hypothesis" to explain patterns of spawning in southeastern Australian fishes in response to seasonal pattern of river flow. Milton and Arthington (1983; 1984; 1985) suggested that small sub-tropical stream fishes recruit successfully by spawning in the months of low and relatively stable stream flows when their spawning habitats are least likely to be scoured out or stranded. Similar seasonal patterns of reproductive activity are emerging in many sub-tropical and tropical fish species (Arthington and Pullar 1990; Pusey and others 2001) and have also been recorded in freshwater turtles (Cann 1998) and the platypus, Ornithorhynchus anatinus (Grant 1984).

In contrast to low flow spawning, other aquatic species are cued to increases in flow or the timing of large floods (Lowe-McConnell 1985; Welcomme 1985). In southeastern Alaska, coho salmon (Oncorhynchus kisutch) enter many rivers for reproduction at the onset of autumn rains in September and October, whereas in Washington and Oregon Rivers entry is delayed until the rains start in November (Naiman and others 2002, this volume). The timing of rising flows may also serve as a cue or "trigger' to the spawning of certain fish species. Examples are the Colorado River squawfish (Ptychocheilus lucius) in the Yampa River (Nesler and others 1988), and the Clanwilliam yellowfish (Barbus capensis) in South Africa (King and others 1998). In large floodplain rivers, many aquatic species ranging from benthic microorganisms, phytoplankton, zooplankton, and fish are cued to rising flood levels, emerging from resting stages or spawning in response to the cue of rising water levels and inundation. 
Influence of modified temperature regimes on life history patterns

In many regulated river systems modified flow regimes are accompanied by major shifts in the thermal regime, especially where dams have hypolimnetic water releases (Crisp and others 1983; Travnichek and others 1993) leading to the release of cold oxygen-deficient water downstream. Since aquatic insects and fish use the combined cue of day-length and the summation of daydegrees to synchronize emergence as adults, the release of cooler water downstream of impoundments can influence the spawning behaviour of fish and life history processes of invertebrates (Penaz and Jurajda 1995) (Table 2). In the long-term, hypolimnetic releases can cause selective disappearance of susceptible species from downstream reaches. Modified thermal patterns and day-length cues have been shown not only to disrupt insect emergence patterns but also to reduce population success (Ward and Stanford 1982). Coldwater releases have been found to delay spawning by up to 30 days in some fish species (Zhong and Power 1996).

\section{Principle 3: Maintenance of natural patterns of longitudinal and lateral connectivity is essential to the viability of populations of many riverine species.}

\section{Longitudinal connectivity}

The viability of populations of many species of fully aquatic organisms depends on their ability to move freely through the stream network. Large migratory macroinvertebrates such as shrimps and crabs are an important component of the biota of tropical and subtropical streams because of their direct influence on ecosystem level processes, such as primary production, organic matter processing, sedimentation and the composition of benthic algal and invertebrate communities (Pringle and others 1993; Pringle and Blake 1994; Pringle 1996). Water abstraction and the construction of dams can have a major impact on the migration of large shrimp (Pringle and Scatena 1999) (Table 3). For example, damming of the lower reaches of one of the main drainages of the Caribbean National Forest in Puerto Rico has had a major impact on shrimp recruitment. More than 50\% of migrating larvae were drawn into water intakes for municipal supplies and juvenile shrimps returning upstream faced severe predation below the dam (Pringle and Scatena 1999). Cessation of water abstraction during evening periods of peak nocturnal 
larval drift, upkeep of a functional fish ladder and maintenance of a minimum flow could significantly reduce impacts of the dam and its operations.

Diadromous fishes, which migrate long distances within the main channels and larger tributaries of rivers, are particularly sensitive to barriers to longitudinal passage because obstruction of their migratory pathways may interfere with the completion of their life cycles (Table 3). The disappearance or decline of the major migratory fish species often follows river impoundment and the blocking of passage in the system (Bonetto and others 1989, Cadwallader 1986, Harris 1984a, b; Joy and Death 2001, Welcomme 1985, 1992). For example, an extensive network of hydroelectric dams, constructed between 1939 and 1975, has blocked access to or inundated most riverine habitat suitable for spawning by fall chinook salmon (Oncorhynchus tshawytscha) in the Columbia River basin (Dauble and Geist 2000). More that 75\% of the original 2,500 km of mainstem spawning and rearing habitats has been eliminated. Although dam passage requirements have dramatically mitigated direct mortality, Snake River spring/summer populations are expected to decline toward extinction unless there are modest reductions in firstyear mortality or estuarine mortality (Kareiva and others 2000). Migratory species such as shad, lamprey and eels have disappeared from the Rhone River in France and the Guadalquivir River in Spain (Reyes-Gavilan and others 1996). In New Zealand, Joy and Death (2001) found that fish species richness in Taranaki Ring Plain streams was significantly reduced above dams due to their influence on movements of diadromous species.

In-stream barriers have contributed to the decline of populations of migratory fish species in southern Australia, such as Australian bass, Macquarie perch, and golden perch (Lake and Marchant 1990, Barmuta and others 1992). Barriers have affected between 30-50\% of the potential habitat for migratory fish in 22 coastal drainages in southeastern Australia (Harris 1984a). Less than $10 \%$ of these barriers had fish-ways and, of these, only 6 of the 29 provided suitable conditions for fish migration at the time surveyed (Harris 1984b). River impoundment and the blocking of fish passage are often followed by the disappearance or decline of the major migratory species in river reaches upstream of barriers; this has been observed for Australian bass in east coast river systems (Harris 1984a, b).

It is important to note that the impact of barriers on mobile organisms is not confined to very large structures. Even small in-stream barriers, such as v-notch gauging weirs, can impede the 
movement of fish (e.g., western minnows Galaxias occidentalis in south-western Australian forest streams - Pusey and others 1989).

\section{Lateral connectivity}

Hydrological connectivity between the river channel, floodplain, and groundwater structures the spatio-temporal heterogeneity of floodplain habitats (Ward and Stanford 1995), leading to characteristic high biodiversity (Ward and others 1999). The lateral expansion of floodplain habitats during flooding creates important spawning, nursery and foraging areas for many fish species and a variety of other vertebrates (Lowe-McConnell 1985; Welcomme 1985; Cadwallader 1986; Junk and others 1989; Ward and others 1999). The extent and duration of river flooding during the wet season can determine whether and for how long fish can gain access to nursery habitats and food (Bayley 1991; Heiler and others 1995), and whether fish will remain trapped in isolated floodplain waterbodies or are released back into the river system (Lowe-McConnell 1985). Mortality of fish trapped in dry season refuges may be very high due to deteriorating physicochemical conditions, reductions in food availability, and lack of refuge from predators (Kushlan 1976, Lowe-McConnell 1985, Woodland and Ward 1990). In turn, the duration and frequency of connection during periods of high flow (Halyk and Balon 1983, Hillman 1986), periodic isolation of floodplain waterbodies and the proximity of such habitats to the main river channel are important in determining the composition of fish assemblages (Kushlan 1976; Hickley and Baley 1986; Lloyd and Walker 1986).

Flow regulation by dams, often compounded by other structural modifications such as channelization and levee banks, normally results in reduced connectivity and altered successional trajectories in floodplain rivers (Ward and Stanford 1995). Dams typically dampen flood peaks, reducing the frequency, extent and often the duration of floodplain inundation. Smaller channelforming flows modify patterns of channel migration, lowering habitat diversification on the floodplain. These changes ultimately reduce the biological diversity and ecological integrity of floodplain rivers (Ward and Stanford 1995) (Table 3).

Prior to river regulation, many species of fish in Australian rivers were thought to have used inundated floodplain wetlands of lowland rivers for breeding and juvenile habitat (Geddes and Puckridge 1989). River regulation to prevent flooding has seriously affected such recruitment 
(Cadwallader and Lawrence 1990), and there is an obvious trend of reduced native species abundance with increasingly regulated catchments (e.g., Gehrke and others 1995). On the Macquarie River in eastern Australia, the Macquarie Marshes, a hemispheric wetland reserve for water birds have been reduced to $40-50 \%$ of their original size by flow diversions and weirs (Kingsford and Thomas 1995). Low flows have eroded river channels, further reducing flows onto the floodplain, and a water diversion channel and levee banks have alienated parts of the floodplain from the river, and retained floodwater on other parts for periods of more than 12 months. The area with river red gums halved between 1934 and 1981, as did the area of reed beds between 1963 and 1972 (Brander 1987). Over several hundreds of hectares of coolibahs (Eucalyptus coolibah) flooded behind levee banks have died since the 1970s. Abundance and species richness of water birds in the northern part of the Macquarie Marshes has declined over an 11-year period (Kingsford and Thomas 1995).

\section{Principle 4: The invasion and success of exotic and introduced species in rivers is facilitated by the alteration of flow regimes}

For the purposes of this review, the term exotic (i.e., non-native) species is defined as those that are not indigenous to a country. The term introduced is used more generally to refer to any species intentionally or accidentally released into an environment outside its natural range (Welcomme 1988). Exotic species are favored by many changes to flow regime, and the first three principles help to explain why some exotic plants and animals are so successful under modified flow conditions.

\section{Influence of altered flow regimes on invasions}

The loss of wet-dry cycles in floodplain wetlands often has major ecological impacts that favor exotic species. In Australia stable water levels may reduce the growth and survival of native aquatic macrophytes and encourage the invasion of Typha spp and introduced water hyacinth (Eichhornia crassipes) (Kingsford 2000).

Although fish species have been introduced into a wide variety of environments, the greatest success has been achieved in waters which have been dammed, diverted, and otherwise modified, creating permanent standing water (reservoirs) and more constant flow regimes than 
previously existed (e.g., Moyle 1986, Arthington and others 1990) (Table 4). Long-term success (integration) of an invading fish species is much more likely in an aquatic system permanently altered by human activity than in a lightly disturbed system (Moyle and Light 1996a). The most successful invaders will be those adapted to the modified flow regime (Moyle and Light 1996b).

Moyle and Light (1996a,b) argue that failure of exotic fish species to establish populations in Californian (USA) streams is best attributed to their inability to adapt to abiotic conditions (rather than as a result of the biotic resistance of the recipient community). Invasions of nonnative fishes into Deer Creek, an unmodified tributary of the Sacramento River, have failed, prevented primarily by the natural flow regime (Baltz and Moyle 1993).

Regulation of flows in some Australian rivers is thought to favor exotic fish species such as carp Cyprinus carpio and mosquitofish Gambusia affinis (Pusey and others 1989, Faragher and Harris 1994, Walker and others 1995, Gehrke and others 1999). These species appear to benefit from seasonally stable, low flows and may displace native species adapted to more variable flows and heterogeneous habitat conditions. Common carp, tench Tinca tinca, and European perch Perca fluviatilis have remained relatively insignificant in some Australian rivers for decades, whereas they have been favored by the increased stability of river flows in the Murray-Darling system (Cadwallader 1986). Gehrke and others (1999) have shown that regulated rivers in the MurrayDarling system have a lower diversity than relatively undisturbed rivers further inland, with the reduction in diversity largely due to greatly increased numbers of carp in regulated reaches.

\section{Influence of conversion of lotic to lentic habitat on biological invasions}

Long-term success (integration) of an invading species is much more likely in an aquatic system permanently altered by human activity than in a lightly disturbed system (Moyle and Light 1996a). Most prominently, this is due to the fact that human disturbed systems (e.g., reservoirs) resemble one another over broad geographic areas and favor species that are also favored by humans (Gido and Brown 1999). Creating permanent standing water bodies and/or more constant flow regimes by damming or diverting river flows favors introduced species, many of which are most abundant in lakes and river backwaters in their native range (Moyle 1986).

Dominance of aquatic macrophyte communities in slow flowing and impounded river reaches by exotic species, such as the water hyacinth (Eichhornia crassipes) is a common occurrence. With 
its free-floating habit and rapid growth rate, the hyacinth can form dense surface growths covering large areas of open water, interfering with flow and water transport, disrupting recreation, impeding the access of stock to water, and blocking light penetration (Mitchell and Gopal 1991).

Conversion of rivers to lentic habitat can lead to the proliferation of exotic species of fish, for example tilapia Oreochromis mossambicus in large dams in Africa, Sri Lanka, and Australia (Arthington and Blühdorn 1994). However, conversion to lake habitat is not always perceived to be bad news. For example, the Lake Tanganyika sardine (or “kapenta”) Limnothrissa miodon was introduced to Lake Kariba. Between the first introduction in the 1960s and late 1990s, it has developed into a thriving fishery producing 25,000 t per annum, with a piscivore Hydrocynon vittatus, feeding on the sardine and forming another important fishery (Davies and Day 1998). Although once thought too small and puny to survive turbulent passage through hydroelectric turbines and sluice gates of Kariba Dam, the sardine has successfully invaded Lake Cahora Bassa (a reservoir) in Mozambique, more than $200 \mathrm{~km}$ downstream (Davies and Day 1998).

\section{Interbasin transfers of water}

Although accidental or deliberate movement of propagules (e.g., stocking) are likely to be the most important mechanisms, alteration of flow regimes and the infrastructure associated with it are also major contributors to the spread of introduced and exotic aquatic species. Historical patterns of species distributions, local endemicity and metapopulation structure of aquatic organisms are largely determined by catchment boundaries and the presence of natural in-stream barriers (e.g., waterfalls) (Meffe and Vrijenhoek 1988; Bunn and Hughes 1997; Pusey and others 1998). Interbasin water transfers can alter natural distribution patterns of aquatic biota and enhance the spread of pests and diseases (as well as presenting serious problems in terms of water balance, water quality and the disruption of significant ecological processes). Such schemes are increasing in popularity as the number of sites suitable for dam construction and the scale of individual decline (Boon 1992).

The South African Orange-Vaal River Project, the Orange-Fish-Sundays River Inter-catchment Transfer Scheme and the Tugela-Vaal Water Transfer Scheme provide examples of the impacts of interbasin transfers on biological invasions (Cambray and others 1986) (Table 4). The 
transfer of endemic flora and fauna between catchments has occurred with a variety of consequences (Skelton 1986). Inter-basin transfers of schistosomes in the Orange-Vaal Scheme into rivers previously free of schistosomiasis have been enhanced by temperature changes below large dams that affect the dynamics of both the snail host and parasite populations (Pitchford and Visser 1975). The catfish Clarias gariepinnus has invaded the Great Fish River through the inter-catchment transfer tunnel from Lake Verwoerd and has become established in the Sundays River system (Skelton 1986) and there has also been some spread of aquatic macrophytes. Four species of fish have been introduced from the Orange River drainage to the Great Fish River drainage via interbasin water transfers, presumably transferred as eggs or larvae.

\section{Uncertainty and the role of science}

There can be no question that the natural flow regime has a profound influence on the biodiversity of streams, rivers and their floodplain wetlands (Poff and others 1997, Hart and Finelli 1999). There are clearly several interrelated causal mechanisms operating over different temporal and spatial scales and no one characteristic of the flow is responsible (Figure. 1). As a consequence, it is often difficult to resolve which attributes of the altered flow regime are directly responsible for observed impacts (e.g. is the decline of a fish species due to reduced capacity to migrate under altered peak flows or because of a change in substrate composition of spawning areas, or both?). An obvious constraint to resolving this is the potential lag effect in biological response to flow alteration. In particular, impacts to aquatic biota caused by changes in physical habitat (Principle 1) may not directly coincide with actual changes in flow regime because of longer time scales for channel adjustment.

Despite this, there is growing recognition that certain aspects of the flow regime are important for particular ecological processes (e.g., to trigger fish migration and spawning, and rejuvenate floodplains). However, river managers now wish to predict how far these attributes can be altered from their natural state, before an impact occurs. For example, "what will be the impact of reducing a particular flow attribute from a current level of 10\% less than natural to $20 \%$ less?" Similarly, managers need to be convinced that providing additional environmental flows (e.g., by clawing back irrigation allocations at considerable cost) can produce some demonstrable environmental benefit. Our limited ability to predict and quantify the biotic response to flow 
regulation is a major constraint to achieving ecological sustainability (Bunn 1999, Naiman and others 1995, Richter and others 1997).

Perhaps a greater challenge to resolving this problem is the separation of direct effects of the modified flow regime from impacts associated with land use changes that often accompany water resource development (e.g., conversion of forest to irrigated agriculture). In writing this review, we often encountered reports of river systems affected by multiple stressors and were unable to definitively separate the impacts of altered flow regimes from those of the myriad of other factors and interactions. How much of an observed decline in species diversity can be attributed directly to modified flow compared with diffuse inputs of nutrients and other contaminants? A similar problem occurs in our attempts to unravel cause and effect of exotic species on aquatic biodiversity. Is an observed decline in native fish species the result of a modified flow regime or the direct impact of an introduced species (or both)? Alternatively, is the proliferation of exotic species a direct response to the modified flow or the decline in native species (or both)? Ecological science is not yet able to answer these questions, important as they are.

Ecologists still have much to learn about the ecological significance of individual flow events and sequences of events, and descriptive science can take us only so far in unraveling these linkages. The advice from aquatic ecologists on environmental flows might be regarded at this point in time as a series of largely untested hypotheses about the flows that aquatic organisms need and how rivers function in relation to flow regime. To overcome these problems aquatic science needs to move into a manipulative or experimental phase, either by restoring flows, or taking away flows, and measuring ecosystem response. Hopefully, flow restoration experiments will dominate over flow regulation experiments!

\section{Acknowledgements}

This manuscript was prepared as part of the activities of the Scientific Committee for Water Research. The authors thank the International Council of Science for their financial support and especially Rohini Rao who worked with the Committee. We also thank Fiona Balcombe, Phillip Cassey and Stephen Mackay for providing several key examples for this review, as well as Bob 
Naiman, Lisa Thompson and Christer Nilsson for constructive comments on earlier drafts of the manuscript. Lisa Thompson also kindly edited the final draft manuscript. 


\section{Literature Cited}

Angermeier, P.L. 1987. Spatiotemporal variation in habitat selection by fishes in a small Illinois stream. Pages 52-60 in D. C. Matthews and W. J. Heins (eds.) Community Ecology of North American Stream Fishes. University of Oklahoma Press, London.

Armitage, P.D. 1977. Invertebrate drift in the regulated River Tees, and an unregulated tributary Maize Beck, below Cow Green Dam. Freshwater Biology 7:167-183. (cited in Petts 1984).

Arthington, A.H., and D.R. Blühdorn. 1994. Distribution, genetics, ecology and status of the introduced cichlid, Oreochromis mossambicus, in Australia. Pages 53-62 in D. Dudgeon and P. Lam (eds.) Inland Waters of Tropical Asia and Australia: Conservation and Management. Mitteilungen (Communications), Societas Internationalis Limnologiae 24.

Arthington, A.H., S. Hamlet, and D.R. Blühdorn. 1990. The role of habitat disturbance in the establishment of introduced warm-water fishes in Australia. Pages 61-66 in D.A. Pollard (ed.) Introduced and Translocated Fishes and their Ecological Effects. Bureau of Rural Resources Proceedings No. 8. Australian Government Printing Service, Canberra..

Arthington, A.H., and I. Pullar. 1991. Barker-Barambah Irrigation Project: a case study in integrated management of a catchment-aquatic ecosystem. Pages 781-803 in Proceedings of the 17th Conference of the International Committee on Large Dams (ICOLD), Vienna.

Baltz, D.M., and P.B. Moyle. 1993. Invasion resistance to introduced species by a native assemblage of stream fishes. Ecological Applications 3:246-255.

Barmuta, L.A., R. Marchant, and P.S. Lake. 1992. Degradation of Australian streams and progress towards conservation and management in Victoria. Pages 65-79 in P.J. Boon, P. Calow and G.E. Petts (eds.) River Conservation and Management. John Wiley and Sons, Chichester.

Bayley, P.B. 1991. The flood pulse advantage and the restoration of river-floodplain systems. Regulated Rivers: Research and Management 6:75-86.

Biggs, B.J.F. 1996. Hydraulic habitat of plants in streams. Regulated Rivers: Research and Management 12:131-144.

Blanch, S.J., G.G. Ganf, and K.F. Walker. 1999. Tolerance of riverine plants to flooding and exposure indicated by water regime. Regulated Rivers: Research and Management 15:43-62.

Blanch, S.J., K.F. Walker, and G.G. Ganf. 2000. Water regimes and littoral plants in four weir pools of the River Murray, Australia. Regulated Rivers: Research and Management 16:445-456. 
Bonetto, A.A., J.R. Wais, and H.P. Castello. 1989. The increasing damming of the Paraná Basin and its effect on the lower reaches. Regulated Rivers: Research and Management 4:333-346.

Boon, P.J. 1992. Essential elements in the case for river conservation. Pages 11-33 in P.J. Boon, P. Calow and G.E. Petts (eds.) River Conservation and Management. John Wiley and Sons, Chichester.

Bradford, M.J. 1997. An experimental study of stranding of juvenile salmonids on gravel bars and in side channels during rapid flow fluctuations. Regulated Rivers: Research and Management 13:395-401.

Bradford, M.J., G.C. Taylor, J.A. Allan, and P.S. Higgins. 1995. An experimental study of stranding of juvenile coho salmon and rainbow trout during rapid flow decreases in winter conditions. North American Journal of Fisheries Management 15:473-479.

Brander, D. 1987. Environmental changes in the southern Macquarie Marshes: 1934-87. B.Sc. (Hons) Thesis, University of New South Wales, Sydney (cited in Kingsford 2000).

Bulkley, R.V., C.R. Berry, R. Pimentel, and T. Black. 1981. Tolerances and preferences of Colorado River endangered fishes to selected habitat parameters. Colorado River Fishery Project Final Report Part 3, US Fish and Wildlife Service, Bureau of Reclamation, Salt Lake City, UT (cited in Converse and others 1998).

Bunn, S.E. 1988. Life histories of some benthic invertebrates from streams of the northern jarrah forest. Australian Journal of Marine and Freshwater Research 39:785-804.

Bunn, S.E. 1999. The Challenges of Sustainable Water Use and Wetland Management. Pages 14-22 in: Water: Wet or Dry? Proceedings of the Water and Wetlands Management Conference, November 1998, Nature Conservation Council of NSW, Sydney, NSW. ISBN 0949257249.

Bunn, S.E., and P.I. Boon. 1993. What sources of organic carbon drive food webs in billabongs? A study based on stable isotope analysis. Oecologia 96:85-94.

Bunn, S.E., and J.M. Hughes. 1997. Dispersal and recruitment in streams: Evidence from genetic studies. Journal of the North American Benthological Society 16:338-346.

Bunt, C.M., S.J. Cooke, C. Katopodis, and R.S. McKinley. 1999. Movement and summer habitat of brown trout (Salmo trutta) below a pulsed discharge hydroelectric generating station. Regulated Rivers: Research and Management 15: 395-403. 
Cadwallader, P. 1986. Fish of the Murray-Darling system. Pages 679-694 in B.R Davies and K.F. Walker (eds.) The Ecology of River Systems. Dr W. Junk, Publishers, Dordrecht. Cadwallader, P.L., and B. Lawrence. 1990. Fish. Pages 316-335 in N. Mackay and D. Eastburn (eds.) The Murray. Murray-Darling Basin Commission, Canberra.

Cambray, J.A., B.R. Davies, and P.J. Ashton. 1986. The Orange-Vaal River system. Pages 89122 in B.R Davies and K.F. Walker (eds.) The Ecology of River Systems. Dr W. Junk, Publishers, Dordrecht.

Cann, J. 1998. Australian Freshwater Turtles. Beaumont Publishing, Singapore, 292pp.

Chambers, P.A., E.E. Prepas, H.R. Hamilton, and M.L. Bothwell. 1991. Current velocity and its effects on aquatic macrophytes in flowing waters. Ecological Applications 1:249-257.

Cobb, D.G., and J.F. Flannagan. 1990. Trichoptera and substrate stability of the Ochre River, Manitoba. Hydrobiologia 206:29-38.

Cobb, D.G., T.D. Galloway, and J.F. Flannagan. 1992. Effects of discharge and substrate stability on density and species composition of stream insects. Canadian Journal of Fisheries and Aquatic Sciences 49:1788-1795.

Converse, Y.K., C.P. Hawkins, and R.A. Valdez. 1998. Habitat relationships of subadult humpback chub in the Colorado River through the Grand Canyon: spatial variability and implications of flow regulation. Regulated Rivers: Research and Management 14:267-284.

Copp, G.H. 1989. The habitat diversity and fish reproductive function of floodplain ecosystems. Environmental Biology of Fishes 26:1-26.

Copp, G.H. 1990. Effect of regulation on 0+ fish recruitment in the Great Ouse, a lowland river. Regulated Rivers: Research and Management 5:251-163.

Crisp, D.T., R.H.K. Mann, and P.R. Cubby. 1983. Effects of regulation of the river Tees upon fish populations below Cow Green reservoir. Journal of Applied Ecology 20:371-386.

Dauble, D.D., and D.R. Geist. 2000. Comparison of mainstem spawning habitats for two populations of fall chinook salmon in the Columbia River basin. Regulated Rivers: Research and Management 16:345-361.

Davies, B., and J. Day. 1998. Vanishing Waters. University of Cape Town Press, Cape Town, 487pp. 
De Jalon, D.G., P. Sanchez, and J.A. Camargo. 1994. Downstream effects of a new hydropower impoundment on macrophyte, macroinvertebrate and fish communities. Regulated Rivers: Research and Management 9:253-261.

De Moor, F.C. 1986. Invertebrates of the Lower Vaal River, with emphasis on the Simuliidae. Pages 135-142 in B.R. Davies and K.F. Walker (eds.) The Ecology of River Systems. Dr W. Junk, Publishers, Dordrecht.

De Silva, K.H.G.M. 1988a. Studies of Atyidae (Decapoda, Caridinea) of Sri Lanka. III. Aspects of the population ecology of Caridina simoni Bouvier, 1904. Crustaceana 54:85-103.

De Silva, K.H.G.M. 1988b. Studies of Atyidae (Decapoda, Caridinea) of Sri Lanka. IV. Some aspects of the population ecology of the endemic freshwater shrimp Caridina pristis Roux, 1931. Crustaceana 54:225-243.

Edwards, R.J. 1978. The effect of hypolimnion releases on fish distribution and species diversity. Transactions of the American Fisheries Society 107:71-77. (cited in Petts 1984).

Faragher, R.A., and J.H. Harris. 1994. The historical and current status of freshwater fish in New South Wales. Australian Zoologist 29:166-176.

Felley, J.D., and S.M. Felley. 1987. Relationships between habitat selection by individuals of a species and patterns of habitat segregation among species: fishes of the Calcasieu drainage. Pages 61-68 in D.C. Matthews and W.J. Heins (eds.) Community Ecology of North American Stream Fishes. University of Oklahoma Press, London.

Finlayson, C.M., J. Roberts, A.J. Chick, and P.J.M. Sale. 1983. The biology of Australian weeds. II. Typha domingensis Pers. and Typha orientalis Presl. Journal of the Australian Institute of Agricultural Science 1983:3-10.

French, T.D., and P.A. Chambers. 1996. Habitat partitioning in riverine macrophyte communities. Freshwater Biology 36:509-520.

Frissel, C.A., W.J. Liss, C.E. Warren, and M.D. Hurley. 1986. A hierarchical framework for stream habitat classification: viewing streams in a watershed context. Environmental Management 10:199-214.

Froend, R.H., and A.J. McComb. 1994. Distribution, productivity and reproductive phenology of emergent macrophytes in relation to water regimes at wetlands of South-western Australia. Australian Journal of Marine and Freshwater Research 45:1491-1508. 
Geddes, M.C., and J.T. Puckridge. 1989. Survival and growth of larval and juvenile native fish: the importance of the floodplain. Pages 101-116 in Proceedings of a Workshop on Native Fish Management, Canberra. Murray-Darling Basin Commission, Canberra.

Gehrke, P.C., P. Brown, C.B. Schiller, D.B. Moffatt, and A.M. Bruce. 1995. River regulation and fish communities in the Murray-Darling River system, Australia. Regulated Rivers: Research and Management 11:363-375.

Gehrke, P.C., P. Brown, and C.B. Schiller. 1999. Australian native fish, river regulation and carp: the Paroo perspective. Pages 201-222 in R.T. Kingsford (ed.) A Free-flowing River: The Ecology of the Paroo River. NSW National Parks and Wildlife Service, Hurstville, Australia.

Gido, K.B., and J.H. Brown. 1999. Invasion of North American drainages by alien fish species. Freshwater Biology 42:387-399.

Gore, J.A. 1977. Reservoir manipulations and benthic macroinvertebrates in a prairie river. Hydrobiologia 55:111-123. (cited in Petts 1984).

Gorman, O.T., and J.R. Karr. 1978. Habitat structure and stream fish communities. Ecology 59:507-515.

Grant, T. 1984. The Platypus. New South Wales University Press, Kensington, 76 pp.

Halyk, L.C., and E.K. Balon. 1983. Structure and ecological production of the fish taxocene of a small floodplain system. Canadian Journal of Zoology 61:2446-2464.

Hancock, M.A., and S.E. Bunn. 1997. Population dynamics and life history of Paratya australiensis Kemp, 1917 (Decapoda: Atyidae) in upland rainforest streams, south-east Queensland. Marine and Freshwater Research 48:361-369.

Harris, J.H. 1984a. A survey of fishways in streams of coastal south-eastern Australia. Australian Zoologist 21:219-233.

Harris J.H. 1984b. Impoundment of coastal south-eastern Australia, and a review of its relevance to fish migrations. Australian Zoologist 21:235-250.

Hart, D.D., and C.M. Finelli. 1999. Physical-biological coupling in streams: The pervasive effects of flow on benthic organisms. Annual Review of Ecology and Systematics 30:363-395.

Heiler, G., T. Hein, and F. Schiemer. 1995. Hydrological connectivity and flood pulses as the central aspects for the integrity of a river-floodplain system. Regulated Rivers: Research and Management 11:351-361. 
Henricson, J., and K. Müller. 1979. Stream regulation in Sweden with some examples from Central Europe. Pages 183-200 in J.V. Ward and J.A. Stanford (eds.) The Ecology of Regulated Streams. Plenum Press, New York. (cited in Petts 1984).

Hickley, P., and R.G. Bailey. 1986. Fish communities of the perennial wetland of the Sudd, southern Sudan. Freshwater Biology 16:695-709.

Hillman, T.J. 1986. Billabongs. Pages 457-470 in P. DeDekker and W. D. Williams (eds.) Limnology in Australia. CSIRO/Junk, Dordrecht.

Hubbs, C., and J. Pigg. 1976. The effects of impoundments on threatened fishes of Oklahoma. Annals of the Oklahoma Academy of Science 5:133-177. (cited in Petts 1984).

Humphries P., and P.S. Lake, 2000. Fish larvae and the management of regulated rivers. Regulated Rivers Research and Management 16: 421-432.

Humphries, P., A.J. King, and J.D. Koehn, 1999. Fish, flows and floodplains: links between freshwater fishes and their environment in the Murray-Darling River system, Australia. Environmental Biology of Fishes 56: 129-151.

Joy, M.K., and R.G. Death. 2001. Control of fish and crayfish community structure in Taranaki, New Zealand: dams, diadromy or habitat structure. Freshwater Biology 46:417-429.

Jubb, R.A. 1972. The J.G. Strydom Dam: Pongolo River: northern Zululand. The importance of floodplain pans below it. Piscator 86, 104-109. (cited in Petts 1984).

Junk, W.J., P.B. Bayley, and R.E. Sparks. 1989. The flood-pulse concept in river-floodplain systems. Pages 110-127 in D.P. Dodge (ed.) Proceedings of the International Large River Symposium (LARS), Canadian Journal of Fisheries and Aquatic Sciences Special Publication 106.

Kareiva, P., M. Marvier, and M. McClure. 2000. Recovery and management options for spring/summer chinook salmon in the Columbia River Basin. Science 290:977-979.

King J.M., J.A. Cambray, and D.N. Impson. 1998. Linked effects of dam-released floods and water temperature on spawning of the Clanwilliam yellowfish Barbus capensis. Hydrobiologia 384:245-265.

Kingsford, R.T. 2000. Ecological impacts of dams, water diversions and river management on floodplain wetlands in Australia. Austral Ecology 25:109-127. 
Kingsford, R.T., and R.F. Thomas. 1995. The Macquarie Marshes in arid Australia and their waterbirds: a 50 year history of decline. Environmental Management 19:867-878.

Kraft, M.E. 1972. Effects of controlled flow reduction on a trout stream. Journal Fisheries Research Board of Canada 29:1405-1411.

Kroger, R.L. 1973. Biological effects of fluctuating water levels in the Snake River, Grand Teton National Park, Wyoming. The American Midland Naturalist 89:478-481. (cited in Petts 1984).

Kushlan, G.A. 1976. Environmental stability and fish community diversity. Ecology 57:821-825.

Lake P.S. 1975. Fish of the Murray River. Pages 213-224 in G.C. Lawrence and G.K. Smith (eds.) The Book of the Murray. Rigby, Adelaide. (cited in Petts 1984).

Lake P.S., L.A. Barmuta, A.J. Boulton, I.C. Campbell, and R.M. St. Clair. 1985. Australian streams and Northern Hemisphere stream ecology: comparisons and problems. Proceedings of the Ecological Society of Australia 14:61-82.

Lake, P.S., and R. Marchant. 1990. Australian upland streams: ecological degradation and possible restoration. Proceedings of the Ecological Society of Australia 16: 79-91.

Layzer, J.B., T.J. Nehus, W. Pennington, J.A. Gore, and J.M. Nestler. 1989. Seasonal variation in the composition of drift below a peaking hydroelectric project. Regulated Rivers: Research and Management 3:305-317.

Lehmkuhl, D.M. 1972. Change in thermal regime as a cause of reduction of benthic fauna downstream of a reservoir. Journal of the Fisheries Research Board of Canada 29:13291332. (cited in Petts 1984).

Lillehammer, A., and S.J. Saltveit. 1979. Stream regulation in Norway. Pages 201-214 in J.V. Ward and J.A. Stanford (eds.) The Ecology of Regulated Streams. Plenum Press, New York. (cited in Petts 1984).

Lloyd, L.N., and K.F. Walker. 1986. Distribution and conservation status of small freshwater fish in the River Murray, South Australia. Transactions of the Royal Society of South Australia 110:49-57.

Lowe-McConnell, R.H. 1985. Ecological studies in tropical fish communities. Cambridge University Press, Cambridge, London, 302pp.

Lundqvist, J. 1998. Avert looming hydrocide. Ambio 27:428-33. 
Marchant, R., A. Graesser, L. Metzeling, P. Mitchell, R. Norris, and P. Suter. 1984. Life histories of some benthic insects from the La Trobe River, Victoria. Australian Journal of Marine and Freshwater Research 26:113-153.

Matthews, W.J. 1985. Critical current speeds and microhabitats of the benthic fishes, Percina roanoka and Etheostoma flabellare. Environmental Biology of Fishes 12:303-308.

Meffe, G.K., and A.L. Sheldon. 1988. The influence of habitat structure on fish assemblage composition in southeastern blackwater streams. The American Midland Naturalist 120:225240.

Meffe, G.K., and R.C. Vrijenhoek. 1988. Conservation genetics in the management of desert fishes. Conservation Biology 2:157-167.

Milton, D.A., and A.H. Arthington. 1983. Reproduction and growth of Craterocephalus marjoriae and C. stercusmuscarum (Pisces: Atherinidae) in south-eastern Queensland, Australia. Freshwater Biology 13:589-597.

Milton, D.A., and A.H. Arthington. 1984. Reproductive strategy and growth of the crimson-spotted rainbow fish, Melanotaenia splendida fluviatilis (Castelnau) (Pisces: Melanotaeniidae) in southeastern Queensland. Australian Journal of Marine and Freshwater Research 35:75-83.

Milton, D.A., and A.H. Arthington. 1985. Reproductive strategy and growth of the Australian smelt, Retropinna semoni (Weber) (Pisces : Retropinnidae), and the olive perchlet, Ambassis nigripinnis (de Vis) (Pisces : Ambassidae), in Brisbane, south-eastern Queensland. Australian Journal of Marine and Freshwater Research 36:329-41.

Mitchell, D.S., and B. Gopal. 1991. Invasion of tropical freshwaters by alien aquatic plants. Pages 139-154 in P.S. Ramakrishnan (ed.) Ecology of Biological Invasions in the Tropics. Published for National Institute of Ecology by International Scientific Publications, New Delhi.

Moyle, P.B. 1986. Fish introductions into North America: patterns and ecological impact. Pages 27-43 in H.A. Mooney and J.A. Drake (eds.) Ecology of Biological Invasions of North America and Hawaii. Springer-Verlag, New York, USA.

Moyle, P.B., and T. Light. 1996a. Biological invasions of fresh water: empirical rules and assembly theory. Biological Conservation 78:149-161.

Moyle, P.B., and T. Light. 1996b. Fish invasions in California: do abiotic factors determine success? Ecology 77:1666-1670. 
Mullan, J.W., V.J. Staroska, J.L. Stone, R.W. Wiley, and W.J. Wiltzius. 1976. Factors affecting Upper Colorado River Reservoir tailwater trout fisheries. Pages 405-423 in J.F. Orsborn and C.E. Allman (eds.) Instream Flow Needs, Vol. II. American Fisheries Society, Bethesda, Maryland, USA. 657pp. (cited in Petts 1984).

Munn, M.D., and M.A. Brusven. 1991. Benthic invertebrate communities in nonregulated and regulated waters of the Clearwater River, Idaho, USA. Regulated Rivers: Research and Management 6:1-11.

Naiman, R.J., J.J. Magnuson, D.M. McKnight, and J.A. Stanford. 1995. The Freshwater Imperative: A Research Agenda. Island Press, Washington, D.C., 165pp.

Naiman, R.J., S.E. Bunn, C. Nilsson, G.E. Petts, G. Pinay, and L.C. Thompson. 2002. Legitimizing fluvial ecosystems as users of water: an overview. Environmental Management (this volume).

Nesler, T.P., R.T. Muth, and A.F. Wasowicz. 1988. Evidence for baseline flow spikes as spawning cues for Colorado squawfish in the Yampa River, Colorado. Transactions of the American Fisheries Society Symposium 5:68-79.

Newbury, R., and M. Gaboury. 1993. Exploration and rehabilitation of hydraulic habitats in streams using principles of fluvial behaviour. Freshwater Biology 29:195-210.

Nilsson, C. and M. Svedmark. 2002. Basic principles and ecological consequences of changing water regimes: riparian plant communities. Environmental Management (this volume)

Penaz, M., and P. Jurajda. 1995. 0+ fish assemblages in a sector of the Rhone River influenced by the Brégnier-Cordon hydroelectric scheme. Regulated Rivers: Research and Management 10:363-372.

Petts, G.E. 1984. Impounded Rivers. Perspectives for Ecological Management. John Wiley and Sons, Chichester. pp 326.

Pitchford, R.J., and P.S. Visser. 1975. The effect of large dams on river water temperature below the dams, with special reference to bilharzia and the Verwoerd Dam. South African Journal of Science 71:212-213.

Poff, N.L., and J.D. Allan. 1995. Functional organization of stream fish assemblages in relation to hydrological variability. Ecology 76:606-627. 
Poff, N.L., and J.V. Ward. 1990. Physical habitat template of lotic systems: recovery in the context of historical patterns of spatiotemporal heterogeneity. Environmental Management 14:629-645.

Poff, N.L., J.D. Allan, M.B. Bain, J.R. Karr, K.L. Prestegaard, B.D. Richter, R.E. Sparks, and J.C. Stromberg. 1997. The natural flow regime. BioScience 47:769-784.

Pringle, C.M. 1996. Atyid shrimps (Decapoda: Atyidae) influence the spatial heterogeneity of algal communities over different scales in tropical montane streams, Puerto Rico. Freshwater Biology 35:125-140.

Pringle, C.M., G.A. Blake, A.P. Covich, K.M. Buzby, and A. Finley. 1993. Effects of omnivorous shrimp in a montane tropical stream: sediment removal, disturbance of sessile invertebrates and enhancement of understorey algal biomass. Oecologia 93:1-11.

Pringle, C.M., and G.A. Blake. 1994. Quantitative effects of atyid shrimp (Decapoda: Atyidae) on the depositional environment in a tropical stream: use of electricity for experimental exclusion. Canadian Journal of Fisheries and Aquatic Sciences 51:1443-1450.

Pringle, C.M., and F.N. Scatena. 1999. Freshwater resource development. Case studies from Puerto Rico and Costa Rica. Pages 114-121 in L.U. Hatch and M.E. Swisher (eds.) Managed Ecosystems: The Mesoamerican Experience. Oxford University Press, New York.

Puckridge, J.T., F. Sheldon, K.F. Walker, and A.J. Boulton. 1998. Flow variability and the ecology of large rivers. Marine and Freshwater Research 49:55-72.

Pusey, B.J., A.H. Arthington, and M.G. Read. 1993. Spatial and temporal variation in fish assemblage structure in the Mary River, south-east Queensland: the influence of habitat structure. Environmental Biology of Fishes 37:355-380.

Pusey, B.J., A.H. Arthington, and M.G. Read. 1995. Species richness and spatial variation in fish assemblage structure in two rivers of the Wet Tropics of Northern Queensland, Australia. Environmental Biology of Fishes 42:181-199.

Pusey, B.J., A.W. Storey, P.M. Davies, and D.H.D. Edward. 1989. Spatial and temporal variation in fish communities in two south-western Australian river systems. Journal of the Royal Society of Western Australia 71:69-75.

Pusey, B.J., A.H. Arthington, and M.G. Read. 1998. Freshwater fishes of the Burdekin River, Australia: biogeography, history and spatial variation in assemblage structure.

Environmental Biology of Fishes 53:303-318. 
Pusey, B.J., M.J. Kennard, and A.H. Arthington. 2000. Discharge variability and the development of predictive models relating stream fish assemblage structure to habitat in north-eastern Australia. Ecology of Freshwater Fishes 9:30-50.

Pusey, B.J., A.H. Arthington, J. Bird, and P.G. Close. 2001. Reproduction in three species of rainbowfishes (Melanotaeniidae) from rainforest streams in northern Queensland, Australia. Ecology of Freshwater Fish 10:75-87.

Radford, D.S., and R. Hartford-Rowe. 1971. A preliminary investigation of bottom fauna and invertebrate drift in an unregulated and regulated stream in Alberta. Journal of Applied Ecology 8:883-903. (cited in Petts 1984).

Rea, N., and G.G. Ganf. 1994. The role of sexual reproduction and water regime in shaping the distribution patterns of clonal emergent aquatic plants. Australian Journal of Marine and Freshwater Research 45:1469-1479.

Reiser, D.W., T.A. Wesche, and C. Estes. 1989. Status of instream flow legislation and practice in North America. Fisheries 14:22-29.

Resh, V.H., A.V. Brown, A.P. Covich, M.E. Gurtz, H.W. Li, G.W. Minshall, S.R. Reice, A.L. Sheldon, J.B. Wallace, and R.C. Wismaar. 1988. The role of disturbance in stream ecology. Journal of the North American Benthological Society 7:433-455.

Reyes-Gavilan, F.G., R. Garrido, A.G. Nicieza, M.M. Toledo, and F. Brana. 1996. Fish community variation along physical gradients in short streams of northern Spain and the disruptive effect of dams. Hydrobiologia 321:155-163.

Richter, B.D., J.V. Baumgartner, R. Wigington, and D.P. Braun. 1997. How much water does a river need? Freshwater Biology 37:231-249.

Rørslett, B. 1988. Aquatic weed problems in a hydroelectric river: the R. Otra, Norway. Regulated Rivers: Research and Management 2:25-37.

Rørslett, B., M. Mjelde, and S.W. Johansen. 1989. Effects of hydropower development on aquatic macrophytes in Norwegian Rivers: present state of knowledge and some case studies. Regulated Rivers: Research and Management 3:19-28.

Sagar, P.M. 1986. The effects of floods on the invertebrate fauna of a large, unstable braided river. New Zealand Journal of Marine and Freshwater Research 20:37-46.

Sand-Jensen, K., and T.V. Madsen. 1992. Patch dynamics of the stream macrophyte, Callitriche cophocarpa. Freshwater Biology 27:277-282. 
Schlosser, I.J. 1982. Fish community structure and function along two habitat gradients in a headwater stream. Ecological Monographs 52:395-414.

Skelton, P.H. 1986. Fish of the Orange-Vaal system. Pages 353-74 in B.R. Davies and K.F. Walker (eds.) The Ecology of River Systems. Dr W. Junk, Publishers, Dordrecht.

Sparks, R.E. 1995. Need for ecosystem management of large rivers and floodplains. BioScience 45:168-182.

Stanford, J.A., and J.V. Ward. 1986a. Reservoirs of the Colorado River system. Pages 375-383 in B.R. Davies and K.F. Walker (eds.) The Ecology of River Systems. Dr W. Junk, Publishers, Dordrecht.

Stanford, J.A., and J.V. Ward. 1986b. Fish of the Colorado River system. Pages 385-402 in B.R. Davies and K.F. Walker (eds.) The Ecology of River Systems. Dr W. Junk, Publishers, Dordrecht.

Sweeney, B.W. 1984. Factors influencing life-history patterns of aquatic insects. Pages 56-90 in V.H. Resh and D.M. Rosenberg (eds.) The Ecology of Aquatic Insects. Praeger Press, USA. Trautman, M.B., and D.K. Gartman. 1974. Re-evaluation of the effects of man-made modification on Gordon Creek between 1887 \& 1973 and especially as regards to fish fauna. Ohio Journal of Science 74:162-173. (cited in Petts 1984).

Travnichek, V.H., A.V. Zale, and W.L. Fisher. 1993. Entrainment of ichthyoplankton by a warmwater hydroelectric facility. Transactions of the American Fisheries Society 122:709716.

Trotzky, H.M., and R.W. Gregory. 1974. The effects of water flow manipulation below a hydroelectric power dam on the bottom fauna of the upper Kennebec River, Maine. Transactions of the American Fisheries Society 103:318-324. (cited in Petts 1984).

Valentin, S., Y. Souchon, and J.G. Wasson. 1994. Evaluation of hydro-peaking effects on fish community and habitat. Pages 138-151 in I.G. Crown (ed.) Rehabilitation of Freshwater Fisheries. Fishing News Books, Oxford.

Valentin, S., J.G. Wasson, and M. Philippe. 1995. Effects of hydropower peaking on epilithon and invertebrate community trophic structure. Regulated Rivers: Research and Management 10:105-119.

Vannote R.L., G.W. Minshall, K.W. Cummins, J.R. Sedell, and C.E. Cushing. 1980. The river continuum concept. Canadian Journal of Fisheries and Aquatic Sciences, 37:130-137. 
Walker, K.F., M.C. Thoms, and M.C. Sheldon. 1992. Effects of weirs on the littoral environment of the River Murray, South Australia. Pages 271-92 in P.J. Boon, P. Calow and G.E. Petts (eds.) River Conservation and Management. John Wiley and Sons, Chichester.

Walker, K.F., A.J. Boulton, M.C. Thoms, and F. Sheldon. 1994. Effects of water-level changes induced by weirs on the distribution of littoral plants along the River Murray, South Australia. Australian Journal of Marine and Freshwater Research 45:1421-1438.

Walker, K.F., F. Sheldon, and J.T. Puckridge. 1995. An ecological perspective on dryland rivers. Regulated Rivers: Research and Management 11:85-104.

Ward, J.V., and R.A. Short. 1978. Macroinvertebrate community structure of four special lotic habitats in Colorado, USA. Verhandlungen Internationale Vereiningung für Theoretische und Angewandte Limnologie 20:1382-1387. (cited in Petts 1984).

Ward, J.V., and J.A. Stanford. 1982. Thermal responses in the evolutionary ecology of aquatic insects. Annual Review of Entomology 27:97-117

Ward, J.V., and J.A. Stanford. 1995. Ecological connectivity in alluvial river ecosystems and its disruption by flow regulation. Regulated Rivers: Research and Management 11:105-119.

Ward, J.V., K. Tockner, and F. Schiemer. 1999. Biodiversity of floodplain ecosystems: ecotones and connectivity. Regulated Rivers: Research and Management 15:125-139.

Welcomme, R.L. 1979. Fisheries Ecology of Floodplain Rivers. Longman, London and New York, USA. 317pp. (cited in Petts 1984).

Welcomme, R.L. 1985. River Fisheries. FAO Fisheries Technical Paper 262. Food and Agriculture Organisation of the United Nations, Rome. 330 pp.

Welcomme, R.L. 1988. International introductions of inland aquatic species. FAO Fisheries Technical Paper 294, Food and Agriculture Organisation of the United Nations, Rome. 318 pp.

Welcomme, R.L. 1992. River conservation - Future prospects. Pages 454-462 in P.J. Boon, P. Calow and G.E. Petts (eds.) River Conservation and Management. John Wiley and Sons, Chichester.

Wetmore, S.H., R.J. Mackay, and R.W. Newbury. 1990. Characterisation of the hydraulic habitat of Brachycentrus occidentalis, a filter feeding caddisfly. Journal of the North American Benthological Society 9:157-169. 
Wetzel, R.G. 1990. Land-water interfaces: metabolic and limnological regulators. Verhandlungen der Internationalen Vereinigung für Limnologie 24:6-24.

Whitley, J.R., and R.S. Campbell. 1974. Some aspects of water quality and biology of the Missouri River. Transactions of the Missouri Academy of Science 8:60-72. (cited in Petts 1984).

Williams, R.D., and R.H. Winget. 1979. Macroinvertebrate response to flow manipulation in the Strawberry River, Utah (USA). Pages 365-377 in J.V. Ward and J.A. Stanford (eds.) The Ecology of Regulated Streams. Plenum Press, New York. (cited in Petts 1984).

Winterbourn, M.J., J.S. Rounick, and B. Cowie. 1981. Are New Zealand stream ecosystems really different? New Zealand Journal of Marine and Freshwater Research 15:321-328.

Woodland, D.J., and P.J. Ward. 1990. Fish communities in sandy pools of Magela Creek, Alligator Rivers Region. Research Report 9. Supervising Scientist for the Alligator Rivers Region, 81pp.

Zhong, Y., and G. Power. 1996. Environmental impacts of hydroelectric projects on fish resources in China. Regulated Rivers: Research and Management 12:81-98. 
Table 1: Summary of biotic responses to altered flow regimes, in relation to flow induced changes in habitat (Principle 1). Additional examples (in italics) to those included in this review are from Petts (1984).

\begin{tabular}{|c|c|c|}
\hline $\begin{array}{l}\text { Flow variables } \\
\text { affected }\end{array}$ & Biotic responses & Sources \\
\hline \multirow{4}{*}{$\begin{array}{l}\text { Increased stability } \\
\text { of baseflow and } \\
\text { reduction of flow } \\
\text { variability }\end{array}$} & $\begin{array}{l}\text { Excessive growths of aquatic } \\
\text { macrophytes }\end{array}$ & $\begin{array}{l}\text { Rørslett 1988; Røslett and others 1989; Walker } \\
\text { and others 1994; French and Chambers 1996; } \\
\text { Blanch and others } 2000\end{array}$ \\
\hline & $\begin{array}{l}\text { Proliferation of nuisance larval } \\
\text { blackflies }\end{array}$ & De Moor 1986 \\
\hline & Reduction in fish populations & Converse and others 1998 \\
\hline & $\begin{array}{l}\text { Increased standing crop and reduced } \\
\text { diversity of macroinvertebrates }\end{array}$ & $\begin{array}{l}\text { Armitage 1977; Ward and Short 1978; } \\
\text { Lillehammer and Saltveit 1979; Williams and } \\
\text { Winget } 1979\end{array}$ \\
\hline \multirow{4}{*}{$\begin{array}{l}\text { Erratic (diurnal) } \\
\text { patterns in flow } \\
\text { below } \\
\text { hydroelectric dams }\end{array}$} & $\begin{array}{l}\text { Reduction in species richness of } \\
\text { benthic macroinvertebrates }\end{array}$ & $\begin{array}{l}\text { Munn and Brusven 1991; Mullan and others } \\
\text { 1976; Trotzky and Gregory } 1974\end{array}$ \\
\hline & $\begin{array}{l}\text { Reduction in standing crop of benthic } \\
\text { macroinvertebrates }\end{array}$ & $\begin{array}{l}\text { Layzer and others 1989; Mullan and others } \\
\text { 1976; Trotzky and Gregory 1974; Radford and } \\
\text { Hartland-Rowe } 1971\end{array}$ \\
\hline & Stranding of macroinvertebrates & Kroger 1973 \\
\hline & Stranding of fish & Bradford 1997; Bradford and others 1995 \\
\hline \multirow{2}{*}{$\begin{array}{l}\text { Conversion of } \\
\text { lotic habitat to } \\
\text { lentic }\end{array}$} & $\begin{array}{l}\text { Decline of populations of riverine } \\
\text { crayfish and snails }\end{array}$ & Walker and others 1992 \\
\hline & $\begin{array}{l}\text { Elimination of salmonids and pelagic } \\
\text { spawning fishes and dominance of } \\
\text { generalist fish species }\end{array}$ & Copp 1990 \\
\hline
\end{tabular}


Loss of fishes adapted to turbid river

habitats

Loss of fishes due to inundation of spawning grounds
Stanford and Ward 1986a

Hubbs and Pigg 1976 
Table 2: Summary of life history responses to altered flow regimes (Principle 2). Additional examples (in italics) to those included in this review are from Petts (1984). (*Note - some examples are based on studies of responses to variation in natural flow regimes).

\begin{tabular}{|c|c|c|}
\hline $\begin{array}{l}\text { Flow variables } \\
\text { affected }\end{array}$ & Biotic responses & Sources \\
\hline $\begin{array}{l}\text { Rates of water } \\
\text { level fluctuation }\end{array}$ & $\begin{array}{l}\text { Aquatic macrophyte growth rates and } \\
\text { seedling survival }\end{array}$ & $\begin{array}{l}\text { Blanch and others 1999; 2000; Froend and } \\
\text { McComb 1994; Rea and Ganf } 1994\end{array}$ \\
\hline \multirow[t]{2}{*}{ Timing of spates } & $\begin{array}{l}\text { Reduced survivorship of larval atyid } \\
\text { shrimps following early summer spates }\end{array}$ & *Hancock and Bunn 1997 \\
\hline & $\begin{array}{l}\text { Stable low flows required for spawning } \\
\text { and recruitment of riverine fish }\end{array}$ & $\begin{array}{l}\text { *Milton and Arthington 1983; 1984; } \\
\text { 1985; Humphries and Lake } 2000\end{array}$ \\
\hline $\begin{array}{l}\text { Reduced } \\
\text { seasonality }\end{array}$ & $\begin{array}{l}\text { Reduced synchrony of breeding in } \\
\text { gammarid shrimps }\end{array}$ & *Bunn 1988 \\
\hline $\begin{array}{l}\text { Timing of rising } \\
\text { flows }\end{array}$ & $\begin{array}{l}\text { Loss of cues for fish spawning and } \\
\text { migration }\end{array}$ & $\begin{array}{l}\text { Lowe-McConnell 1985; Nesler and others } \\
\text { 1988; King and others } 1998\end{array}$ \\
\hline $\begin{array}{l}\text { Short-term } \\
\text { fluctuations in } \\
\text { flows }\end{array}$ & $\begin{array}{l}\text { Adverse effect on species of stoneflies } \\
\text { with long larval development times } \\
\text { (autumn/winter) }\end{array}$ & Henricson and Müller 1979 \\
\hline \multirow[t]{3}{*}{$\begin{array}{l}\text { Modified } \\
\text { temperature } \\
\text { regimes below } \\
\text { dams }\end{array}$} & $\begin{array}{l}\text { Delayed spawning in fish } \\
\text { Disrupted insect emergence patterns }\end{array}$ & $\begin{array}{l}\text { Zhong and Power } 1996 \\
\text { Lehmkuhl 1972; Gore 1977; Ward and } \\
\text { Stanford } 1982\end{array}$ \\
\hline & Reduced benthic standing crop & Lehmkuhl 1972 \\
\hline & $\begin{array}{l}\text { Elimination of temperature-specific } \\
\text { species of fish }\end{array}$ & Trautman and Gartman 1974 \\
\hline
\end{tabular}


Table 3: $\quad$ Summary of biotic responses to the loss of longitudinal or lateral connectivity (Principle 3). Additional examples (in italics) to those included in this review are from Petts (1984).

\begin{tabular}{|c|c|c|}
\hline $\begin{array}{l}\text { Flow variables } \\
\text { affected }\end{array}$ & Biotic responses & Sources \\
\hline Water abstraction & Reduction in migrating shrimp larvae & Pringle and Scatena 1999 \\
\hline \multirow[t]{2}{*}{$\begin{array}{l}\text { Presence of in- } \\
\text { stream barriers }\end{array}$} & $\begin{array}{l}\text { Increased predation on juvenile } \\
\text { migrating shrimp }\end{array}$ & Pringle and Scatena 1999; \\
\hline & Loss of migratory fish species & $\begin{array}{l}\text { Hubbs and Pigg 1976; Welcomme 1979; } \\
\text { Harris 1984a, b; Dauble and Geist 2000; } \\
\text { Kareiva and others 2000; Reyes-Gavilan and } \\
\text { others 1996; Joy and Death } 2001\end{array}$ \\
\hline \multirow[t]{3}{*}{$\begin{array}{l}\text { Reduced frequency, } \\
\text { duration and area of } \\
\text { inundation of } \\
\text { floodplain wetlands }\end{array}$} & $\begin{array}{l}\text { Reduced spawning areas and/or } \\
\text { recruitment success of lowland river } \\
\text { fish }\end{array}$ & $\begin{array}{l}\text { Jubb 1972; Whitley and Campbell 1974; } \\
\text { Lake 1975; Welcomme 1979; Geddes and } \\
\text { Puckridge 1989; Cadwallader and Lawrence } \\
\text { 1990; }\end{array}$ \\
\hline & $\begin{array}{l}\text { Decline in waterbird species richness } \\
\text { and abundance }\end{array}$ & Kingsford and Thomas 1995 \\
\hline & Decline in wetland vegetation & Kingsford 2000 \\
\hline
\end{tabular}


Table 4: Summary of biotic responses to altered flow regimes, in relation to invasion and success of exotic and introduced species (Principle 4). Additional examples (in italics) to those included in this review are from Petts (1984).

\begin{tabular}{|c|c|c|}
\hline $\begin{array}{l}\text { Flow variables } \\
\text { affected }\end{array}$ & Biotic responses & Sources \\
\hline $\begin{array}{l}\text { Loss of wet-dry } \\
\text { cycles and } \\
\text { increased stability } \\
\text { of water levels }\end{array}$ & $\begin{array}{l}\text { Reduced growth and survival of } \\
\text { native aquatic macrophytes and } \\
\text { increased invasion of exotics }\end{array}$ & Kingsford 2000; Mitchell and Gopal 1991 \\
\hline $\begin{array}{l}\text { Reduced flow } \\
\text { variability and } \\
\text { increased seasonal } \\
\text { stability }\end{array}$ & $\begin{array}{l}\text { Favour populations of exotic fish } \\
\text { species (carp, mosquitofish) }\end{array}$ & $\begin{array}{l}\text { Edwards 1978; Faragher and Harris 1994; } \\
\text { Walker and others 1995; Gehrke and others } \\
1999\end{array}$ \\
\hline $\begin{array}{l}\text { Conversion of lotic } \\
\text { to lentic habitat }\end{array}$ & Proliferation of exotic fish species & $\begin{array}{l}\text { Arthington and Bluhdorn 1994; Davies and } \\
\text { Day } 1998\end{array}$ \\
\hline $\begin{array}{l}\text { Interbasin transfers } \\
\text { of water }\end{array}$ & $\begin{array}{l}\text { Transfer of schistosomiasis; } \\
\text { translocation of fish species }\end{array}$ & $\begin{array}{l}\text { Pitchford and Visser 1975; Skelton 1986; } \\
\text { Cambray and others } 1986\end{array}$ \\
\hline
\end{tabular}




\section{Aquatic biodiversity and natural flow regimes}

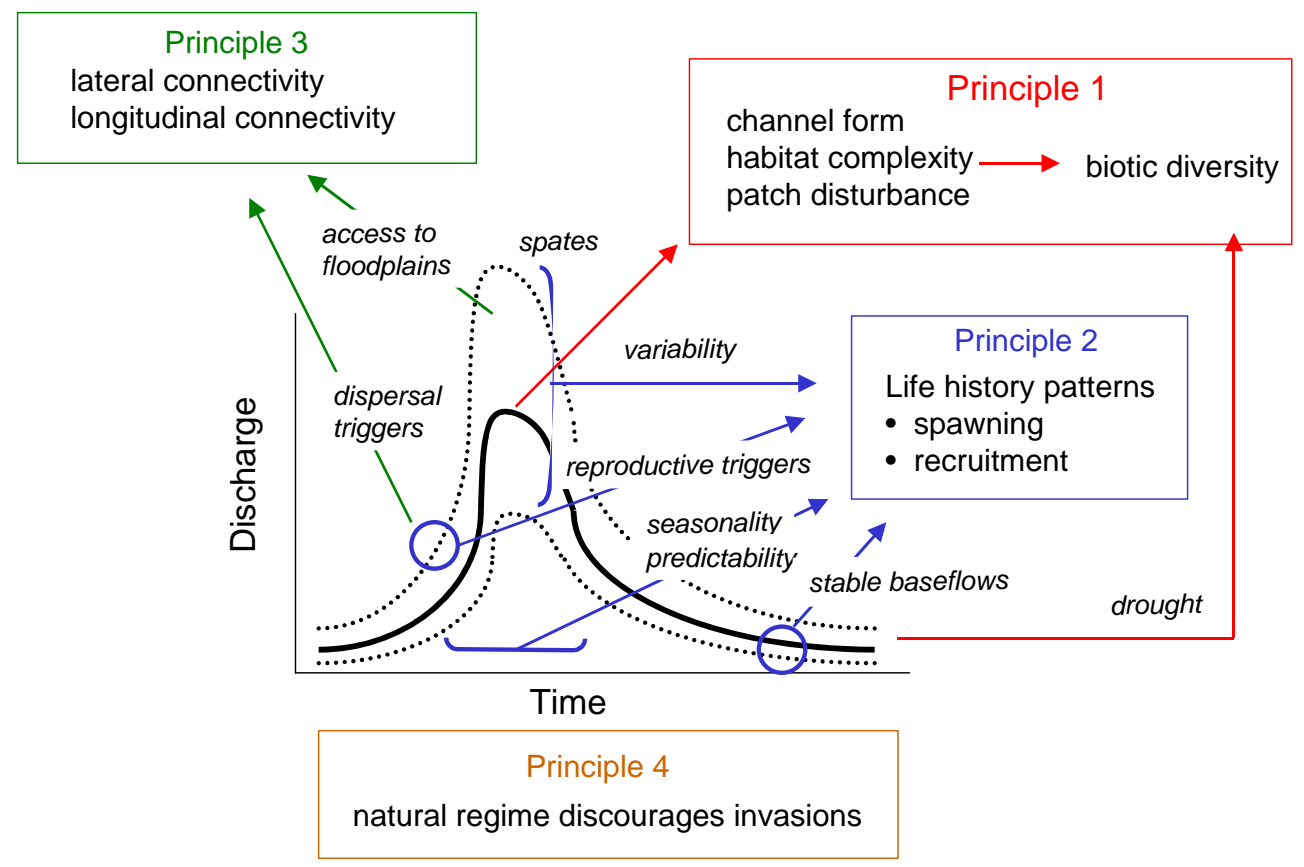

Figure 1. The natural flow regime of a river influences aquatic biodiversity via several, interrelated mechanisms that operate over different spatial and temporal scales. The relationship between biodiversity and the physical nature of the aquatic habitat is likely to be driven primarily by large events that influence channel form and shape (Principle 1). However, droughts and low flow events are also likely to play a role by limiting overall habitat availability. Many features of the flow regime influence life history patterns, especially the seasonality and predictability of the overall pattern, but also the timing of particular flow events (Principle 2). Some flow events trigger longitudinal dispersal of migratory aquatic organisms and other large events allow access to otherwise disconnected floodplain habitats (Principle 3). The native biota has evolved in response to the overall flow regime. Catchment land-use change and associated water resource development inevitably lead to changes in one or more aspects of the flow regime resulting in declines in aquatic biodiversity via these mechanisms. Invasions by introduced or exotic species are more likely to succeed at the expense of native biota if the former are adapted to the modified flow regime (Principle 4). 